\title{
Influence of Grievance Handling Process on Conflict Management in Public Universities in Nakuru County, Kenya
}

\author{
Abisai Ambenge Oyigo (Corresponding author) \\ Student, School of Business and Economics, Mount Kenya University, Kenya \\ E-mail: aoambenge@yahoo.com \\ Dr. Vincent Ntabo \\ Lecturer, School of Business and Economics, Mount Kenya University, Kenya
}

\begin{abstract}
Conflict management is an integral pillar for any organization to achieve its goals and objectives. Due to unpredictable trends in the labor force market, today, organizations are challenged to lay down policies and procedures that can help resolve workers grievances. The primary objective of this research was to examine the influence of grievance handling process on conflict management in public universities in Nakuru County. The study adopted a descriptive research design methodology and with the population being drawn from six selected public universities in Nakuru County. From the selected universities, 147 employees were targeted. The primary data for analysis was collected through a questionnaire using closed-ended questions. The regression analysis reveals that Provision of grievance capturing systems contributes $30.5 \%$, Grievance handling process contributes $31.9 \%$ to conflict management in public universities in Nakuru county. The study concludes that availability of grievance handling process helps in resolving conflicts. Employees in public universities in Nakuru County agreed that grievance handling process have impact on conflict management. This implies that when grievance handling process in an organization is enhanced conflict management could be realized. Therefore, It can be noted that grievance handling process may act as a problem-solving tool in which all the parties of interest are put in picture concerning the underlying problems at the workplace with a purpose of refining the state of affairs. From the research, it was recommended that public university departments should ensure that grievance handling process and function of the system is transparent. The registration system or mechanism should be readily available accessible to all staff/employees to use whenever they have a grievance that needs registration and should be easy and simpler to use.
\end{abstract}

Keywords: Conflict, Grievance, Handling, Management, Process.

DOI: $10.7176 / \mathrm{EJBM} / 11-30-08$

Publication date:October $31^{\text {st }} 2019$

\section{Introduction}

Grievance is referred to as any displeasure apropos to work in the workplace filed formally by any worker or workers concerning his/her work to their immediate supervisor (Rose, 2004). Therefore, it is prudential for institutions to lay down grievance handling procedures, which can be used by workers to file their displeasure regarding their job. The establishment of such procedures is in accordance with the belief of "due process" (ManteMejja\& Enid, 2001), advocating for aset operational procedures in finding justice and ethical decision-making process in an institution.

Grievances always emanate from dissatisfaction among employees. According to Bean (2004), such issues may relate to working facilities, working procedures, or confusion emanating from the provisions provided for in the organization policies

To resolve issues around grievances, as required by the grievance application procedures, the aggrieved file their displeasure to immediate managers or supervisors. The managers or supervisors are then required to find a solution within the required time frame. Therefore, the adopted procedures as per the organization policie sare crucial to deny the construction of the employees' disagreement (Rose, 2004).

Conflict based on social positions, resources, or scarcity of power and divergent value systems occurs when an individual or groups feel that other people have frustrated their plans, beliefs, activities or goals (Dana, 2001). On the other hand, organizational conflicts arise as a result of a struggle between two incompatible or opposing needs, ideas, interests or wishes (Okumbe, 2001). According to Robbins and Coulter (2004), in every organization, conflicts occur at the following four abstract levels: intrapersonal, interpersonal, inter-group and inter-organization. 
Dealing with conflicts in an organization is much linked to the context of conflicts within family, neighborhood, an organization or a country, and how people negotiate during conflict management relates to their personal traits as much as the circumstances surrounding the issue. In 2004, Thomas in his research identified the following five means, which North-Americans use towards conflict negotiation. These include accommodation, avoidance, collaboration, competition, and compromise. Depending on the issue at hand, these methods are used singly or in collaboration depending on persons' personality, skill, knowledge and philosophy. Therefore, organizations or groups may choose to take different negotiation paths to resolve a conflict depending on their history, culture, resources and power. Recently, the Kenyan education has been expanding at a very high rate. This expansion can only be understood within the precepts and continuous demand for education at all levels. From increasing number of admissions to the universities, there is a clear indicator that public universities in Kenya are still on the rise. Thus, this poses a major challenge the education systems and development of human resource. From (MoE, $2014) 1998$ to 2013, there was an increase in the number of conflicts in public universities in Kenya. The number is estimated to have increased from $22(0.9 \%)$ to $300(7.5 \%)$. Additionally, in 2009, different public universities were involved in institutional conflicts. This involved demonstrations and unprotected strikes by all staff or sections of the employees. While in 2016, primary schools also joined the skirmishes of institutional conflicts.

In 2009 alone, Kenyatta University was closed down for one academic year due to student unrest. Other incidences have been noted where university staff have been on strike one after another. The strikes have taken long to resolve which has been a disservice to the Government, students and parents. Despite these challenges, little information is available on the role of grievance handling procedures on the current scenario in public universities in Kenya. And if so, are the staff conversant with the provisions of the same?

\subsection{Statement of the Problem}

From the background of the study, it is apparent that there exists a continued institutional conflict in organizations of higher learning. Specifically, the researcher used public universities in Kenya to explore this knowledge gap by investigating the persistent institutional conflict being experienced in public educational institutions. Besides, the study is geared towards determining the resultant effect of ineffective grievance handling mechanism, which inhibits improved measures of organizational knowledge, increased ability to capture customer value, which affect institutional reputation or survival. Moreover, most educational organizational conflicts are either reported or witnessed today. However, it is not yet clear to what extent or whether grievance capturing system, grievance handling process and grievance handling teams are responsible for the current scenario in public universities. This study investigated the influence of these variables on the management of conflicts in public Universities in Nakuru County. The present study sought to answer the question; How does the grievance handling influence conflict management in Public Universities in Nakuru County?

\subsection{Objective of the Study}

i. To examine the influence of grievance handling process on conflict management in public universities in Nakuru county.

\section{Literature Review}

\subsection{Conceptual Framework}

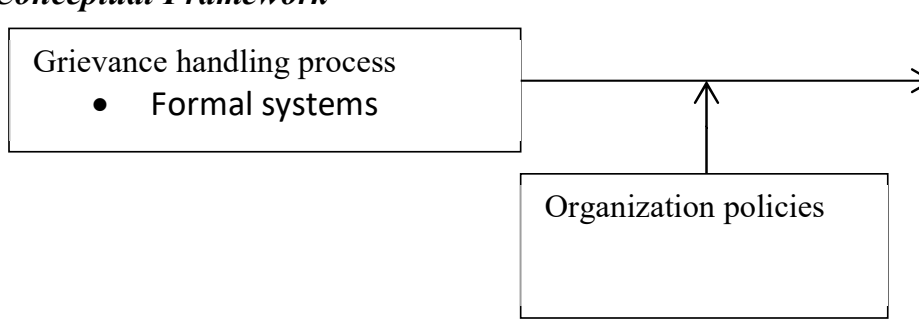

Conflict management

- Avoidance

- Accommodating

\section{Research Design}

Figure 1: Conceptual Framework

Descriptive research design was preferred in this study because it helped the researcher to achieve general overview of the subject matter under study. According to Kothari (2004), descriptive research design is 
defined as a survey and facts finding.

\subsection{Target Population}

Population to which a researcher draws sample size for purposes of study in research was the target population, (Mugenda andMugenda, 2003). The study was conducted in Kenya with a focus on selected public universities in Nakuru County, Kenya. For this study, 6 public universities in Nakuru County were selected (Editor, 2016). Since this number was small, a census study was carried out.

\subsection{Sampling Design and Technique}

Six public universities in Nakuru County were selected in the study. The respondents were categorized into teaching and non-teaching staff. The researcher used stratified random sampling method in this study because itgave a good representation of the population. This sampling method ensured that targeted groups in a population have equal chance in selection in the sample,(Mugenda and Mugenda, 2003). The criterion for stratification was based on categorization of respondents into two strata which will comprise of teaching and non-teaching.

\subsection{Sample Size}

Since the target population was minimal, the study used census method to come with the sample size. A sample size of ten to forty percentages was considered sufficient for a study according to (mugenda and mugenda, 2011). The sample size was as tabulated below in Table 1.

\section{Table 1: Sample Size}

\begin{tabular}{lllll}
\hline University & Non-Teaching & Teaching & Total & Percantage \\
\hline Egerton University-town campus & 44 & 23 & 67 & 45.55 \\
Kenyatta University & 14 & 8 & 22 & 15 \\
JKUAT & 26 & 7 & 33 & 22.45 \\
University of Nairobi & 3 & 2 & 5 & 3.4 \\
Laikipia University & 6 & 7 & 13 & 8.84 \\
Moi University & 4 & 3 & 7 & 4.76 \\
\hline Total & $\mathbf{9 7}$ & $\mathbf{5 0}$ & $\mathbf{1 4 7}$ & $\mathbf{1 0 0}$ \\
\hline
\end{tabular}

\subsection{Instruments and Procedures of Data Collection}

Semi-structured questionnaires were ideal. Mathers, Fox, and Hunn (1998) assert that semi-structured questionnaires as efficient, effective and reliable source of data collection instruments that allow respondents to give opinion in regard to the research questions.

\section{Results}

\subsection{Grievance Handling Process and Conflict Management}

The researcher wanted to explore Grievance Handling Process and conflict management in Public universities in Nakuru County. The findings were analyzed and presented as presented in the Table 2

\section{Table 2: Grievance Handling Teams}

\begin{tabular}{|c|c|c|c|c|}
\hline Grievance Handling Teams & SA & A & D & SD \\
\hline Grievance handling teams influences conflict resolution. & $88 \%$ & $10 \%$ & $2 \%$ & $0 \%$ \\
\hline The organization has adequate number of grievance handling members. & $38.1 \%$ & $45.1 \%$ & $8.8 \%$ & $8.0 \%$ \\
\hline $\begin{array}{l}\text { The grievance handling teams have the required skills and experience in conflict } \\
\text { management. }\end{array}$ & $60.5 \%$ & $36.1 \%$ & $2.0 \%$ & $1.4 \%$ \\
\hline $\begin{array}{l}\text { The grievance handling teams have been empowered by the organization to handle } \\
\text { employee grievances. }\end{array}$ & $40.8 \%$ & $57.2 \%$ & $2 \%$ & $0 \%$ \\
\hline The grievance handling teams encourages employees participation & $72.1 \%$ & $24.5 \%$ & $3.4 \%$ & $0 \%$ \\
\hline The handling process is effective in managing conflict in the university. & $17.7 \%$ & $63.3 \%$ & $12.2 \%$ & $6.8 \%$ \\
\hline Grievance handling process is made known to all employees. & $84.4 \%$ & $9.5 \%$ & $6.1 \%$ & $0 \%$ \\
\hline Grievance handling procedure significantly improves the quality of decision making. & $54.4 \%$ & $43.5 \%$ & $2.1 \%$ & $0 \%$ \\
\hline $\begin{array}{l}\text { Grievance handling process places senior management at the apex of appeal procedure } \\
\text { which serves to confirm and support the existing power structure. }\end{array}$ & $30.6 \%$ & $66.0 \%$ & $3.4 \%$ & $0 \%$ \\
\hline The grievance handling process is straight forward with fewer complications. & $40.8 \%$ & $37.4 \%$ & $21.8 \%$ & $0 \%$ \\
\hline
\end{tabular}


Grievance handling teams influences conflict resolution. This was supported by $98 \%$ of the respondents with only $2 \%$ claiming they do not agree that grievance handling teams influences conflict resolution as a way of conflict management in public universities in Nakuru County. $83.2 \%$ of the respondents said that the organization has adequate number of grievance handling members, while $16.8 \%$ of the respondents did not acknowledge that the organization has adequate number of grievance handling members. 93.6\% of the respondents in this study were confident that grievance handling teams have the required skills and experience in conflict management while only $6.4 \%$ of the respondents did not show confidence in the Grievance handling teams in the public universities in Nakuru County.

The grievance handling teams have been empowered by the organization to handle employee grievances. This was supported by $97.8 \%$ of the respondents who took part in this study. In every organization, managers play critical roles in decision-making process. Thus, if they have good traits, they can help stare the organization to great heights by ensuring all employees grievances are taken care of (Blake et. al, 2008). $96.6 \%$ of the respondents were confident that grievance handling teams encourages employees' participation in conflict management in public universities in Nakuru County. Thomas and Kilmann (1975) labeled this style as collaborating approach. Collaborating mode denotes the ability of a manager to work with his or her employee to find a solution that is agreeable and fully satisfies the concerns of both parties. Grievance handling process is effective in managing conflict in the university. This was supported by $81 \%$ of the respondents who took part in this study. From the analysis, 19\% of the participants in this research are not convinced that grievance handling process is effective in managing conflict in the university. The study further revealed that grievance handling process is made known to all employees in public universities in Nakuru County. The analysis indicated that $93.9 \%$ of the participants are aware ofgrievance handling process in public universities in Nakuru County while only $6.1 \%$ of the employees are not convinced that grievance handling process is made known to all employees in public universities in Nakuru County. With a good structured grievance procedure, union officials or individual employees can challenge the management of an organization over a myriad of issues ranging from wages and working employee-working environment (Lewin, 2008).

The study revealed that grievance handling procedure significantly improves the quality of decision making; places senior management at the apex of appeal procedure which serves to confirm and support the existing power structure and is straight forward with fewer complications.

\subsection{Regression Analysis}

4.2.1The influence of Grievance Handling Process on Conflict Management

Table 3: The influence of Grievance Handling Process on Conflict Management

\begin{tabular}{lccccc}
\hline Model & \multicolumn{2}{c}{$\begin{array}{c}\text { Unstandardized } \\
\text { Coefficients }\end{array}$} & $\begin{array}{c}\text { Standardized } \\
\text { Coefficients }\end{array}$ & t & Sig. \\
\hline & B & Std. Error & Beta & \\
\hline (Constant) & -1.282 & .275 & & -4.664 & .000 \\
Grievance handling process & .319 & .175 & .130 & 1.826 & .072 \\
\hline a. Dependent Variable. Conflict Management & & &
\end{tabular}

a. Dependent Variable: Conflict Management

The regression analysis reveals that Grievance handling process contributes $31.9 \%$ to conflict management in public universities in Nakuru county. Therefore, this study confirms that there is a positive association between grievance handling process and conflict management.

\section{Conclusion}

The research findings indicated that, availability of grievance handling process helps in resolving conflicts. Employees in public universities in Nakuru County alluded that grievance handling process have impact on conflict management. This implies that when grievance handling process in an organization is enhanced conflict management could be realized. Therefore, It can be noted that grievance handling process may act as a problem-solving tool in which all the parties of interest are put in picture concerning the underlying problems at the workplace with a purpose of refining the state of affairs.

\section{Recommendations}

The public university departments should ensure that grievance handling process and function of the system is transparent. The registration system or mechanism should be readily available accessible to all 
staff/employees to use whenever they have a grievance that needs registration and should be easy and simpler to use.

\section{References}

i. $\quad$ Bean, R. (2004). Comparative Industrial Relations: An Introduction to Cross-National Perspectives. 2nd Edition. London: Routledge

ii. $\quad$ Kothari, C. R. (2004). Research methodology: Methods and techniques. New Age International.

iii. Lewin, D. (2008). Resolving conflict. The Sage handbook of industrial relations, 447-467.

iv. Mante-Meija, Enid, A. (2001). Designing an Instrument for Resolving Individual Conflict in "Total "Institution. Knowledge \& Policy, 4(3), 58-73.

v. Mathers, N. J., Fox, N. J., \& Hunn, A. (1998). Surveys and questionnaires. NHS Executive, Trent.

vi. Mugenda, M. O., \& Mugenda, A. G. (2003). Research Methods. Quantitative and Qualitative Approaches. Nairobi: ACTS Press.

vii. Mugenda, A. G. (2011). Social Science Research. Applied Research and Training Services. Nairobi: ACTS Press.

viii. $\quad$ Rose, E. (2004). Employment Relations. 2nd edition. England: Prentice Hall.

ix. Kilmann, R. H., \& Thomas, K. W. (1975). Interpersonal conflict-handling behavior as reflections of Jungian personality dimensions. Psychological Reports, 37(3), 971-980. 